\title{
А.С. Шестопалова
}

\section{«НАЦИОНАЛЬНЫЙ ВОПРОС» В РОССИЙСКОЙ АРМИИ (ПО МАТЕРИАЛАМ ОТЕЧЕСТВЕННОЙ ПУБЛИЦИСТИКИ)}

\author{
Раскрывается содержание «национального вопроса» в армии накануне Первой мировой войны. На основе изучения отече- \\ ственной публицистики с помощью дискурс-анализа предпринята попытка реконструировать представления сторонников \\ исключения инородцев из армии и их оппонентов. \\ Ключевые слова: императорская армия; публицистика; национальный вопрос.
}

В 1874 г. с введения Устава о всеобщей воинской повинности в Российской империи был сделан шаг к реализации идеи всенародной государственной защиты и национальной армии. Это поставило под одни знамена практически все многочисленные народности, проживающие на территории России, и стало началом создания национального государства. В связи с этим актуализировалась проблема лояльности только что принятых в армейскую семью инородцев. Эта проблема является органической частью национального вопроса в России, который особенно остро зазвучал в межреволюционный период и решение которого приобрело особую значимость в судьбоносном для России 1917 г.

В ситуации кризиса царского правительства, Первой русской революции, поражения в русско-японской войне, роста национально-освободительного движения национальный вопрос приобрел сугубо политический характер. Поиск виновных в сложившейся обстановке способствовал культивации мифа о внутреннем враге. На страницах отечественной периодики велось обсуждение степени благонадежности и пригодности для военной службы различных народов Российской империи, была выстроена своеобразная иерархия достойных и недостойных службы в императорской армии. Военно-государственной мыслью была выдвинута и активно пропагандировалась легенда о «необъявленной войне» инородцев против армии. Так кто же считался самым неблагонадежным и нежелательным элементом в армии и как это повлияло на решение национального вопроса в России?

При обсуждении национального вопроса в армии сформировалось два крупных противоборствующих лагеря сторонников и противников присутствия в армии инородцев. Через публицистические статьи они знакомили общественность со своими взглядами и отстаивали свои точки зрения, к которым, сделав свой выбор, должны были примкнуть все слои населения. В реконструкции взглядов представителей этих противостоящих групп заключается цель настоящей работы. Под публицистикой понимаются произведения, цель которых состоит в выражении и формировании общественного мнения по актуальным вопросам современной жизни. Анализ отечественной публицистики открывает перед нами возможность изучения мнений, сформированных в условиях кризиса представителями различных социальных групп. Это обусловило выбор в качестве главного источника статей, опубликованных в «Русском богатстве», «Русском вестнике», «Военном сборнике» и др. Данные журналы в начале XX столетия приобрели публицистический характер, а на их страницах происходило осмысление событий внутренней жизни России. Для достижения поставленной цели мы обратились к дискурс-анализу, с помощью которого предполагается исследовать скрытые смыслы публицистических текстов, контекст создания и возможную их интерпретацию читателями.

По мнению публицистов, главными инициаторами «крестового похода» против величия русской армии стали евреи и поляки при своевременной поддержке финнов и латышей. На другом же полюсе, в качестве приверженных воинов и монархистов с благородным пониманием дисциплины, находились мусульманские подданные [1. С. 392]. Публицистика, прежде всего правого толка, в значительной степени потрудилась над тем, чтобы донести до сознания общественности, офицеров, солдат, что главные внутренние враги отечества - это «бунтовщики, стюденты, конокрады, жиды и поляки» [2. С. 117]. Именно так ответил на занятиях рядовой Овечкин, герой повести «Поединок» А.И. Куприна, опубликованной в мае 1905 г.

Один из главных идеологов молодого русского национализма М.О. Меньшиков в серии публицистических работ, посвященных вопросам жизни и устройства армии, пропагандировал идею о том, что основой государственной армии должно быть только господствующее племя, а враждебных России инородцев, в частности евреев, поляков, армян, следовало бы обложить военной данью. М.О. Меньшиков утверждал, что «золотой век нашей военной славы был тогда, когда армия набиралась из чисто русских» [3. С. 107].

По мере усиления политического кризиса в стране в кругах политической элиты возобладали юдофобские настроения. Несмотря на негативное отношение в военной среде ко многим инородцам, именно евреев объявили главными врагами армии. Постепенно происходило некое отождествление «национального вопроса» и «еврейского вопроса» в армии. Вслед за этим последовал ряд ограничений в военной структуре для представителей еврейской диаспоры, в частности в 1910 г. было запрещено принимать в военные училища 
и производить в офицеры крестившихся евреев [4]. Началась беспрестанная работа по разработке нового воинского Устава, главным достижением которого должно было стать исключение евреев из армии.

Своеобразной подготовкой общества к преобразованиям стала политическая кампания в прессе по дискредитации еврейского населения, его военных способностей. В 1909-1913 гг. выходит большое количество публицистических статей со стороны как явных поборников антисемитизма, так и защитников евреев.

Уже в преддверии Первой русской революции на страницах отечественных периодических изданий зарождались первые мифы о военной службе евреев. Одним из самых распространенных стало убеждение о том, что евреи - это этническая группа, наиболее уклоняющаяся от военной службы. Военный публицист Далинский в своей работе «Евреи в армии» утверждал, что евреи для уклонения от службы прибегали к членовредительству. Он приводил примеры того, как представители еврейской диаспоры за несколько дней до службы ничего не ели, кроме лимонов, пили уксус, вследствие чего принимали болезненный вид, а также вырывали себе нужное количество зубов [5. C. 85]. Эта статья, напечатанная в «Военном сборнике» исследователями признавалась как одна из самых слабых, плохо написанных, неаргументированных за всю историю журнала [6. С. 348].

В политическом руководстве и среди части военных получило признание представление о том, что именно евреи-новобранцы способствовали моральному разложению армии, росту уровня преступности в военной среде. В частности, командир 5-го армейского корпуса Н.В. Шутлеворт в докладе Военному совету 15 января 1908 г. писал, что в армии разрушителями дисциплины являются евреи. Генерал рассуждал так: «Да и какие это воины! В 1904-1905 гг. из всякой части, которая предполагалась к мобилизации, евреи почти все поголовно бежали» [7. Л. 78].

На страницах периодики активно разрабатывался образ евреев как самых ненадежных, плохо обучаемых военному ремеслу, трусливых, подверженных воздействию революционной идеологии [6. С. 15].

Стоит отметить, что эта кампания против евреев в печати касалась исключительно солдат, несмотря на то что среди офицерского корпуса имелись также выходцы из еврейской народности. В периодике некоему осуждению подвергались офицеры, которые снисходительно и сочувственно относились к евреям. М.О. Меньшиков в одной из своих статей упомянул об удачном назначении генерала Мартынова начальником корпуса, охраняющего Манчужурскую дорогу. Публицист так характеризовал генерала: «Он боевой офицер и, кажется, хороший администратор. У него есть драгоценное свойство - быстрота понимания и замечательная решимость. Немножко скомпрометировало его несчастное прикосновение к издательству одной жидо-кадетской газеты, но это было еще в те годы, когда газета, теперь покойная, казалась русской». [8. С. 16]

В межреволюционный период эти стереотипы никуда не ушли, получив лишь законченное оформление и повсеместное распространение. Из многочисленных публикаций праворадикальной публицистики следовал только один вывод: евреев стоит удалить из армии. Приверженцы этой позиции называли евреев не иначе как «антимилитаристами», «анархистами по крови» [1. C. 392].

Острая полемика в Думе по поводу евреев в армии, подготовка нового устава способствовали консолидации лагеря, выступавшего против исключения евреев из армейской семьи. Попытки развеять мифы о военной службе евреев предприняли С. Гинзбург, М. Усов, С.М. Масловский и др. Публицисты с разных позиций пытались доказать необоснованность аргументации приверженцев исключения евреев из армии. В частности, С.М. Масловский (псевдоним С. Мстиславский) утверждал, что «новоявленный русский национализм» для пробы своих сил из многочисленных врагов и противников выбрал евреев как наиболее слабых. Он заявлял, что Военное министерство вопросом об исключении евреев из армии было захвачено врасплох, поскольку до последнего времени еврейского вопроса как такового в армии не существовало [9. С. 1]. Особенной критике публицист подверг стереотип о физической непригодности евреев. Длительное время главным критерием в определении физического развития считалось отношение окружности груди к росту, представители же еврейской диаспоры являлись самым узкогрудым племенем в Российской империи. Но, по мнению Масловского, единственно верным в этой формуле было то, что евреи действительно обладают более узкой грудью, чем другие племена [Там же. С. 5]. Однако тогда бы пришлось признать непригодными для военной службы и афганцев, туркменов и др. Автор призывал обратить внимание на такие характеристики при определении «годности» того или иного народа, как жизненная устойчивость, долголетие, естественный прирост, сопротивляемость болезням. С.М. Масловский подчеркивал, что по всем этим пунктам евреи выгодно отличались от не-евреев [Там же. С. 7].

Приверженцы этой точки зрения считали, что обвинения, выдвинутые против еврея как солдата, не имели реальных оснований и строились лишь на умозрительных заключениях. По их мнению, «еврейство несло свою повинность со всей тщательностью, которую допускал его ослабленный эмиграцией и бытовыми условиями состав» [Там же. С. 26]. Исключение же евреев из армии могло привести от армии государства российского к армии «русского племени».

Противники евреев и сами осознавали шаткость многих своих обвинений, поэтому предприняли попытку подкрепить свои доводы авторитетным мнением военачальников. Для этой цели Военное министерство в 1912 г. разослало анкеты по еврейскому вопросу высшей военной аристократии, знающей об отношении к евреям при дворе и в самом Военном министерстве [6. С. 343]. Большинство из них высказались за изгнание евреев из армии. Многие характеризовали евреев малопригодными либо вообще непригодными к службе в армии. Генералы отмечали физическую слабость и повышенную болезненность евреев, их неприспособленность к физическому труду и тяготам военной службы [4]. Стоит отметить, что материалы анкетиро- 
вания были обработаны значительно позже, а военный устав 1912 г. был принят без их учета. Новый устав, вводивший ряд ограничений для евреев, не исключал их, однако, из армейской семьи.

Широко развернувшаяся кампания против изгнания представителей еврейской национальности из армии лишь с началом Первой мировой войны постепенно блекла, а затем вовсе приняла латентный характер. Взор русской общественности теперь был обращен не к внутреннему врагу, а к внешнему. Но безусловным является и тот факт, что в подсознании многих закрепился образ еврея, лишенного всякого патриотического чувства и желающего гибели для России. Об укреплении этой точки зрения в общественном сознании позаботился Главный штаб, запретив военным цензорам пропускать в печать информацию о подвигах военнослужащих евреев, которые с началом войны, как и все, были призваны на фронт.

Таким образом, активно обсуждавшийся национальный вопрос, частью которого была проблема благонадежности инородцев в российской армии, не был решен до Первой мировой войны. Несмотря на негативное отношение как в армии, так и в обществе к евреям, полякам, финнам, Военное министерство в новом Уставе 1912 г., опасаясь раскола в военной среде накануне мировой войны, не пошло по пути исключения инородцев из армии, в том числе и евреев.

Политическая кампания по исключению евреев и представителей других народностей из армии, развер- нувшаяся на страницах отечественных периодических изданий, по многим параметрам была необоснованной. В военной семье национальный вопрос не стоял так остро, как это было представлено в печати. Но публицистические тексты, появившиеся в 1909-1913 гг., во время обострения политического кризиса, сыграли свою роль в конструировании взаимоотношений в российской армии. Использование дискурсивного анализа позволило установить, что все без исключения публицисты для подтверждения своей точки зрения использовали политический, научный и идеологический дискурсы.

Начало Первой мировой войны отодвинуло решение национального вопроса в армии. К тому же на первых порах реалии военного времени стирали национальную рознь и нетерпимость. Но в армии этот вопрос вспыхнул с новой силой еще до 1917 г., когда по различным соображениям началось создание национальных частей. С началом революции усилились центробежные силы. А.И. Деникин так характеризовал эту ситуацию: «Начались бесконечные национальные военные съезды, заговорили вдруг все языки: литовцы, эстонцы, грузины, белорусы, малороссы, мусульмане... все они требовали немедленного формирования отдельных войск. Должен добавить, что только одна национальность не требовала самоопределения в смысле несения военной службы - это еврейская [10. С. 455]. Цитата А.И. Деникина как ничто другое опровергает тезис националистов о евреях как о неблагонадежном элементе в армии.

\section{ЛИТЕРАТУРА}

1. Евреи и войско // Русский вестник. 1903. № 3. С. 391-393.

2. Куприн А.И. Поединок. М. : Мир книги, 2003.

3. Меньшиков М.О. Из писем к ближним. М. : Воениздат, 1991. С. 105-112.

4. Гольдин С. Русская армия и евреи накануне Первой мировой войны URL: http://www.lechaim.ru/ARHIV/185/goldin.htm\#_ftn23 (дата обращения: 13.03.2017).

5. Далинский. Евреи в армии // Военный сборник. 1911. № 10. С. 75-99.

6. Петровский-Штерн Й. Евреи в русской армии: 1827-1914. М. : Новое литературное обозрение, 2003.

7. Российский государственный военно-исторический архив (РГВИА) Ф. 868. Оп. 1. Д. 822.

8. Меньшиков М.О. Крупные люди // Русский вестник. 1911. № 3. С. 13-18.

9. Масловский С.М. Без евреев // Русское богатство. 1912. № 2. С. 1-35.

10. Деникин А.И. Очерки русской смуты. М. : Айрис-пресс, 2015. Кн. 1, т. 1: Крушение власти и армии (февраль-сентябрь 1917).

Shestopalova Anna S. Omsk State University (Omsk, Russia). E-mail: chestopalova94@mail.ru «NATIONAL ISSUE» IN THE RUSSIAN ARMY (BASED ON DOMESTIC JOURNALISM MATERIALS)

Keywords: imperial army; publicism; national issue.

At the beginning of XX century the problems of everyday life, traditions and life of the imperial army were actively discussed on the pages of Russian periodicals. One of the debatable issues was theme of the degree of trustworthiness and devotion to the Fatherland and the Throne of non-Russians who served in the army.

The purpose of this article is to reconstruct views and arguments of supporters of expelling non-Russians from the army and their opponents. Through publicistic articles, they acquainted the general public with their views. In the present work, journalism is understood to mean works whose purpose is not only to express, but also to form public opinion on topical issues of modern life. The sources of the research were journalistic articles and notes published at the beginning of the XX century in "Russian Wealth", "Russian Herald", "Military Compendium", "Russian Disabled" and other periodicals. One of the fundamental methods of this research is a discourse analysis, which made it possible to reveal the hidden meanings of journalistic texts and their purpose in specific historical conditions, and their possible interpretation by readers.

We found that the most unreliable elements in the army were Jews, Poles, Finns, Latvians and Armenians. But with a negative attitude to representatives of different nationalities, the Jews were declared the main enemies of the Russian army. This fact led to the identification of the "national issue" and "Jewish issue". The article analyzed the myths about servicemen of Jewish origin. The pages of Russian periodicals actively cultivated the idea, that the Jews were the ethnic group, the most deviated from serving military service. Supporters of the expelling of Jewish nationality representatives out of their army characterized the Jewish soldier as poorly trained, unreliable, subject to the influence of revolutionary ideology, contributing to moral decay and increased crime in the troops. This work reconstructed the views of the Jews defenders, the discourse of their texts and rhetoric.

We came to the conclusion that all, without exception, publicists used political, scientific and ideological discourses to confirm their point of view. The combination of different types of discourse in the journalistic texts allowed them to strengthen their arguments and 
influence the formation of public opinion. In many ways, the political campaign of excluding non-Russians from the army, unfolded on the pages of the civil and military periodicals, was not justified. In the army family, the "national question" was not as acute as it was presented in the press.

\section{REFERENCES}

1. Anon. (1903) Evrei i voysko [Jews and the army]. Russkiy vestnik. 3. pp. 391-393.

2. Kuprin, A.I. (2003) Poedinok [Duel]. Moscow: Mir knigi.

3. Menshikov, M.O. (1991) Iz pisem k blizhnim [From letters to neighbors]. Moscow: Voenizdat. pp. 105-112.

4. Goldin, S. (n.d.) Russkaya armiya i evrei nakanune Pervoy mirovoy voyny [Russian Army and Jews on the Eve of the First World War]. [Online] Available from: http://www.lechaim.ru/ARHIV/185/goldin.htm\#_ftn23. (Accessed: 13th March 2017).

5. Anon. (1911) Dalinskiy Evrei v armii [Dalin Jews in the army]. Voennyy sbornik. 10. pp. 75-99.

6. Petrovskiy-Stern, Y. (2003) Evrei v russkoy armii: 1827-1914 [Jews in the Russian army: 1827-1914]. Moscow: Novoe literaturnoe obozrenie.

7. The Russian State Military Historical Archive (RGVIA) Fund 868. List 1. File 822.

8. Menshikov, M.O. (1911) Krupnye lyudi [Big people]. Russkiy vestnik. 3. pp. 13-18.

9. Maslovsky, S.M. (1912) Bez evreev [Without Jews]. Russkoe bogatstvo. 2. pp. 1-35.

10. Denikin, A.I. (2015) Ocherki russkoy smuty [Sketches of Russian Distemper]. Vol. 1(1). Moscow: Ayris-press. 